\title{
A COMPARATIVE ACCOUNT OF THE ROTTING RESISTANCE OF NETTING TWINES OF FIBRES OF VEGETABLE ORIGIN
}

\author{
Hideaki Miyamoto,* G. K. Kuriyan and P. J. Cecily \\ (Received March 7, 1962)
}

Nishmura and Yamazoe (1914) found that cotton twines kept in an aqueous medium, fresh or saline but devoid of bacteria, did not lose their original breaking strength for one year. TERADA (1914) recorded that rotting of netting twine in water is related to the temperature of the suspending medium and that higher the temperature quicker would be the rotting. KawaI (1914) deducted that the rate of rotting is proportional to the temperature of water within a specified range.

TAUTI (1927) is perhaps the first author who attempted an assessment of the amount of rotting and its relation to the resultant strength of the material. His experimental findings were to the effect that loss in breaking strength in thicker twines and ropes by rotting while under continuous immersion in water is proportional to the radius of the material. This view has been corroborated by Мrямото and SHARIFF (1959) in their experiments with sun hemp twines immersed in Cochin backwater.

Kanagawa Prefecture Experimental Fishing Station (1939) made attempts for an evaluation of the rotting resistance of twines made up of different vegetable fibres. They found that twines of cotton, manila and refined ramie were fairly resistant to rotting while crudely manufactured twines of Chinese grass fibre and Japanese hemp possess that property only to a lesser degree. According to Mryamoto and Sharifr (op. cit) Indian sun hemp twines when compared with cotton and manila exhibit less resistance to rotting.

Selection of suitable netting twines and ropes of fibres of vegetable origin for the different gear, apart from other considerations, for reasons of economy is obviously dependent upon the susceptibility or otherwise of the material to rotting. In a country like India, where the majority of fishing gear are still fabricated with vegetable fibre twines and ropes, the evaluation of this inherent property of the different materials assumes importance in the gear research programme. The paucity of data by such studies motivated the present investigations; the rotting resistance properties of the principal gear materials of vegetable origin used in India are discussed.

Central Institute of Fisheries Technology, Cochin, India. Contribution No. 54 .

* FAO/ETP Fishery Specialist with the Government of India. 


\section{Experiments and Results}

(a) Materials: The samples of twines used for the experiments were those of cotton, sun hemp, sisal and coir produced within the country and those of imported Italian

Table 1. Net twines used for the experiments

A

\begin{tabular}{|c|c|c|c|c|c|c|c|}
\hline Material & $\begin{array}{l}\text { Expt. } \\
\text { No. }\end{array}$ & $\begin{array}{l}\text { Specifica- } \\
\text { tion }\end{array}$ & $\begin{array}{l}\text { Weight } \\
(\mathrm{g} / \mathrm{m})\end{array}$ & $\begin{array}{l}\text { Dia. } \\
(\mathrm{mm})\end{array}$ & $\begin{array}{c}\text { Original } \\
\text { Breaking } \\
\text { strength } \\
\text { in wet. } \\
(\mathrm{kg})\end{array}$ & $\begin{array}{c}\text { Period } \\
\text { dipped } \\
\text { in water. }\end{array}$ & Remarks \\
\hline 1 & 2 & 3 & 4 & 5 & 6 & 7 & 8 \\
\hline $\begin{array}{c}\text { Cotton } \\
20^{\prime} \mathrm{S} \\
3 \text { ply } \\
\text { (India) }\end{array}$ & $\begin{array}{l}1 \\
2 \\
3 \\
4 \\
5 \\
6 \\
7 \\
8\end{array}$ & $\begin{array}{l}9 \text { yarns } \\
18 \text { " } \\
30 " \\
48 \text { " } \\
54 \text { " } \\
63 \text { " } \\
79 \text { " } \\
89 \text { " }\end{array}$ & $\begin{array}{l}0.36 \\
0.76 \\
1.25 \\
2.12 \\
2.37 \\
2.66 \\
3.17 \\
3.86\end{array}$ & $\begin{array}{l}0.72 \\
1.04 \\
1.28 \\
1.67 \\
1.78 \\
1.97 \\
2.18 \\
2.29\end{array}$ & $\begin{array}{r}4.83 \\
9.69 \\
14.90 \\
22.78 \\
24.55 \\
27.00 \\
29.80 \\
31.90\end{array}$ & $\begin{array}{c}8-2-60 \\
\text { to } \\
7-4-60\end{array}$ & $\begin{array}{l}\text { Hard twisted } \\
\text { twines. }\end{array}$ \\
\hline $\begin{array}{l}\text { Sun hemp } \\
\text { (India) }\end{array}$ & $\begin{array}{l}1 \\
2 \\
3 \\
4 \\
5 \\
6 \\
7 \\
8 \\
9\end{array}$ & $\begin{array}{ll}3 & \text { ply } \\
4 & \prime \prime \\
6 & \prime \prime \\
7 & \prime \prime \\
8 & \prime \prime \\
9 & \prime \prime \\
2 & \prime \prime \\
3 & \prime \prime \\
3 & \prime\end{array}$ & $\begin{array}{l}0.97 \\
1.32 \\
2.10 \\
2.14 \\
2.56 \\
2.98 \\
1.42 \\
2.03 \\
2.12\end{array}$ & $\begin{array}{l}1.25 \\
1.50 \\
1.95 \\
2.10 \\
2.15 \\
2.34 \\
1.37 \\
1.88 \\
1.66\end{array}$ & $\begin{array}{l}13.2 \\
18.0 \\
21.7 \\
28.9 \\
30.5 \\
40.8 \\
10.8 \\
27.0 \\
25.5\end{array}$ & $\begin{array}{c}25-4-60 \\
\text { to } \\
2-6-60 \\
\\
12.10 .60 \\
\text { to } \\
16.11 .60\end{array}$ & $\begin{array}{l}\text { Tanjore } \\
\text { Dharmadas } \\
\text { Narawekar } \\
\text { A. J. Gandhi }\end{array}$ \\
\hline $\begin{array}{c}\text { Italian } \\
\text { hemp } \\
\text { (Italy) }\end{array}$ & $\begin{array}{l}1 \\
2 \\
3 \\
4 \\
5\end{array}$ & $\begin{array}{c}163 / \mathrm{c} \\
14 \\
10 \\
8 \\
2 \times 4 \text { ply }\end{array}$ & $\begin{array}{l}0.31 \\
0.33 \\
0.49 \\
0.69 \\
3.39\end{array}$ & $\begin{array}{l}0.60 \\
0.63 \\
0.77 \\
0.91 \\
2.08\end{array}$ & $\begin{array}{r}8.2 \\
8.4 \\
11.7 \\
13.5 \\
69.5\end{array}$ & $\begin{array}{c}1-3-60 \\
\text { to } \\
7-4-60\end{array}$ & \\
\hline $\begin{array}{c}\text { Sisal } \\
\text { (India) }\end{array}$ & $\begin{array}{l}1 \\
2 \\
3 \\
4 \\
5\end{array}$ & $\begin{array}{ll}2 & \text { ply } \\
2 & \prime \prime \\
2 & \prime \prime \\
2 & \prime \prime \\
2 & \prime \prime\end{array}$ & & $\begin{array}{l}3.5 \\
2.8 \\
2.8 \\
2.4 \\
2.2\end{array}$ & $\begin{array}{l}45.5 \\
51.8 \\
45.4 \\
40.7 \\
73.6\end{array}$ & $\begin{array}{c}10-6-60 \\
\text { to } \\
5-8-60\end{array}$ & $\begin{array}{l}460 \mathrm{ft} / 1 \mathrm{~b} \\
400 " \\
500 "\end{array}$ \\
\hline $\begin{array}{c}\text { Coir } \\
\text { (India) }\end{array}$ & $\begin{array}{l}1 \\
2 \\
3 \\
4 \\
5\end{array}$ & $\begin{array}{ll}2 & \text { ply } \\
2 & \prime \prime \\
2 & \prime \prime \\
2 & \prime \prime \\
2 & \prime \prime\end{array}$ & & $\begin{array}{l}4.60 \\
4.21 \\
4.60 \\
3.82 \\
4.32\end{array}$ & $\begin{array}{l}24.6 \\
16.4 \\
31.5 \\
21.9 \\
22.0\end{array}$ & $\begin{array}{c}28-3-60 \\
\text { to } \\
13-6-60\end{array}$ & $\begin{array}{l}\text { Real Alapat } \\
\text { Superior Angengo } \\
\text { Imitation Alapat } \\
\text { Ordinary Angengo } \\
\text { Special Mangadan }\end{array}$ \\
\hline
\end{tabular}


Experiments commenced on 3rd May 1961

B

\begin{tabular}{c|c|c|c|c|c}
\hline Name of twine & Specification & (Weight $\mathrm{g} / \mathrm{m})$ & Dia. (mm) & $\begin{array}{c}\text { Original breaking } \\
\text { strength in wet } \\
\text { (kg) }\end{array}$ & Remarks \\
\hline $\begin{array}{c}\text { Cotton } \\
\text { (India) }\end{array}$ & $20 / 25 / 3$ & 3.1 & 2.3 & 29.5 & Hard twisted \\
\hline $\begin{array}{c}\text { Sun hemp } \\
\text { (India) }\end{array}$ & 4 ply & 3.5 & 2.2 & 57.5 & 75.4 \\
\hline $\begin{array}{c}\text { Italian hemp } \\
\text { (Italy) }\end{array}$ & $2 \times 4$ ply & 3.4 & 2.4 & 49.1 & \\
\hline $\begin{array}{c}\text { Manila } \\
\text { (Philippine) }\end{array}$ & 3 ply & 3.7 & 2.7 & 64.0 & Mangadan \\
\hline $\begin{array}{c}\text { Sisal } \\
\text { (India) }\end{array}$ & 2 ply & 3.4 & 3.3 & 22.0 & \\
\hline $\begin{array}{c}\text { Coir } \\
\text { (India) }\end{array}$ & 2 ply & 6.0 & 4.4 & & \\
\hline
\end{tabular}

hemp and manila. The specifications, weight, diameter and the original breaking strength in the wet condition of the twines studied are incorporated in Table 1.

(b) Experimental procedure: The samples of twines of each specification were made into different bundles and immersed in water separately by hanging them from a raft

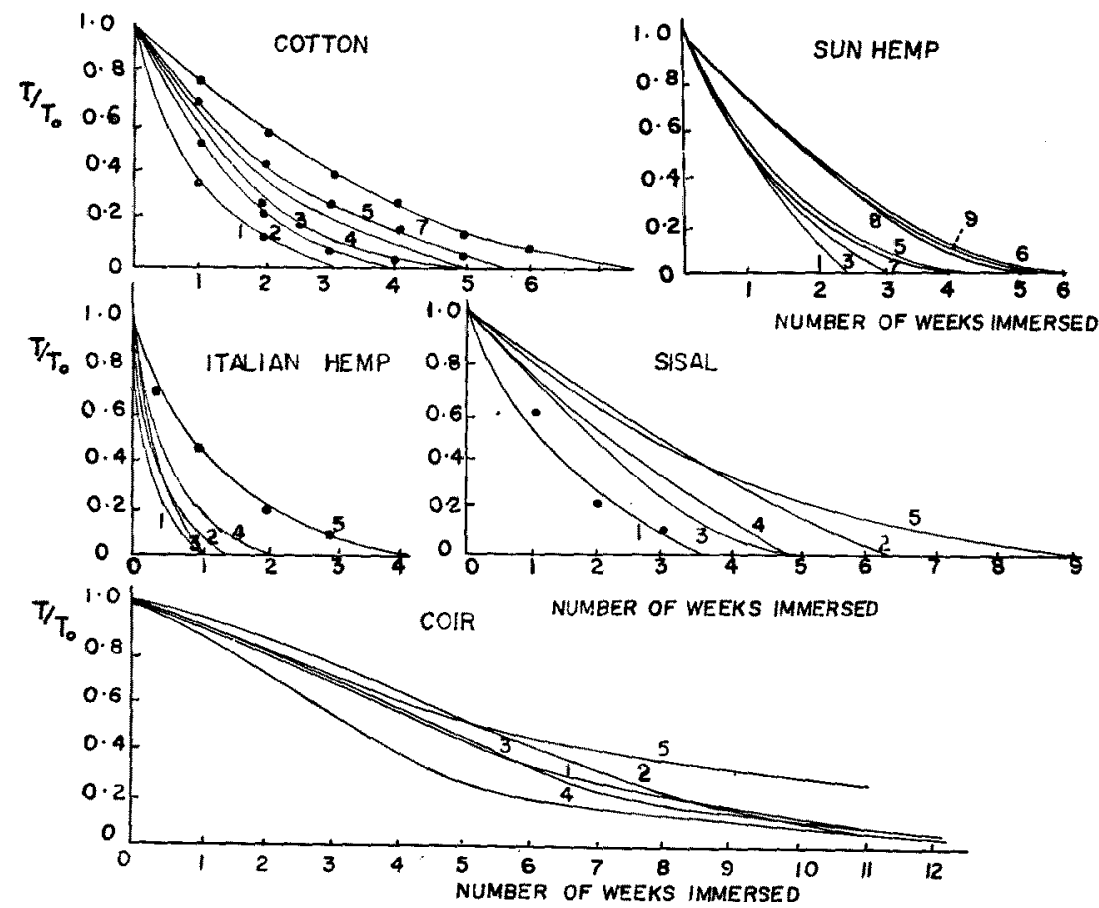

A 


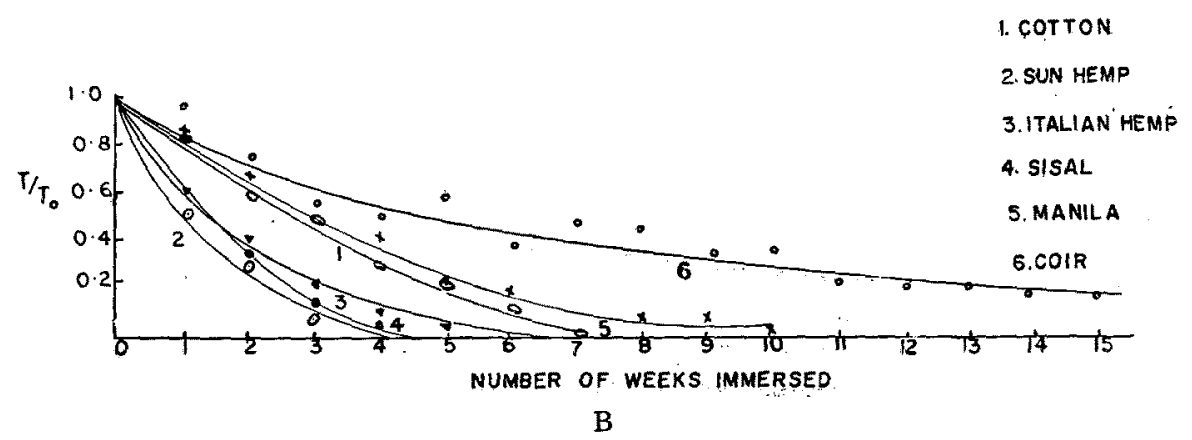

Fig. 1. Results of experiments.

anchored in Cochin backwater. Thereafter, a few pieces of twines were removed from each bundle at specific intervals and tested for their breaking strength in the wet condition. The periods during which the experiments were conducted are indicated in Table 1.

(c) Results: The results of the experiments are presented in Text Fig. 1. The value of $\frac{T}{T_{0}}$ on the $Y$ axis shows the ratio of breaking strength $T$ of twine dipped in water for $t$ days to the original breaking strength $T_{0}$ (vide Table 1 ).

The average temperature and salinity of the test water during the period of May to September 1961 are shown in Table 2.

Table 2. Average water temperature and salinity during the period from May to September 1961.

\begin{tabular}{c|c|c}
\hline Month & Water temperature & Salinity \\
\hline May & $31.3^{\circ} \mathrm{C}$ & 35.3 \\
\hline June & 28.2 & 2.6 \\
\hline July & 27.4 & 3.2 \\
\hline August & 28.7 & 4.3 \\
\hline September & 29.7 & 3.9 \\
\hline
\end{tabular}

\section{Discussion}

It would be clear from Text Fig. 1 that in all the materials studied thinner the twine, quicker is the rotting. Further, sun hemp, Italian hemp and sisal twines are rather weak in the resistance to rotting while cotton, coir and manila are relatively more strong in the resistant property.

Comparison of the rotting resistance: TAUTI (1929) has suggested the following formula to represent the rotting course of a twine dipped in water.

$$
\log \frac{T}{T_{0}-T}=-(K \log e) t+\text { Const. }
$$

where,

$T_{0}=$ Breaking strength of twine dipped in water when the rotting has not yet commenced

$T=$ Breaking strength of twine dipped in water for $t$ days.

$t=$ Number of days the twines were dipped. 
and $K=$ Coefficient of rotting.

It should be obvious that the value of $K$ differs in accordance to the nature of the fibre with which the twines are made, water temperature where the twine is dipped and many other factors.

From the results of the experiments shown in Text Fig. 1, $\log \frac{T}{T_{0}-T}$ and $t \log e$ were calculated and are graphically represented in Text Fig. 2. From this Text Figure the value of $K$ for each srecification of twine was determined and the relation between the value of $K$ and one by diameter of the twine $\left(\frac{1}{D}\right)$ was worked out as shown in Text Fig. 3.
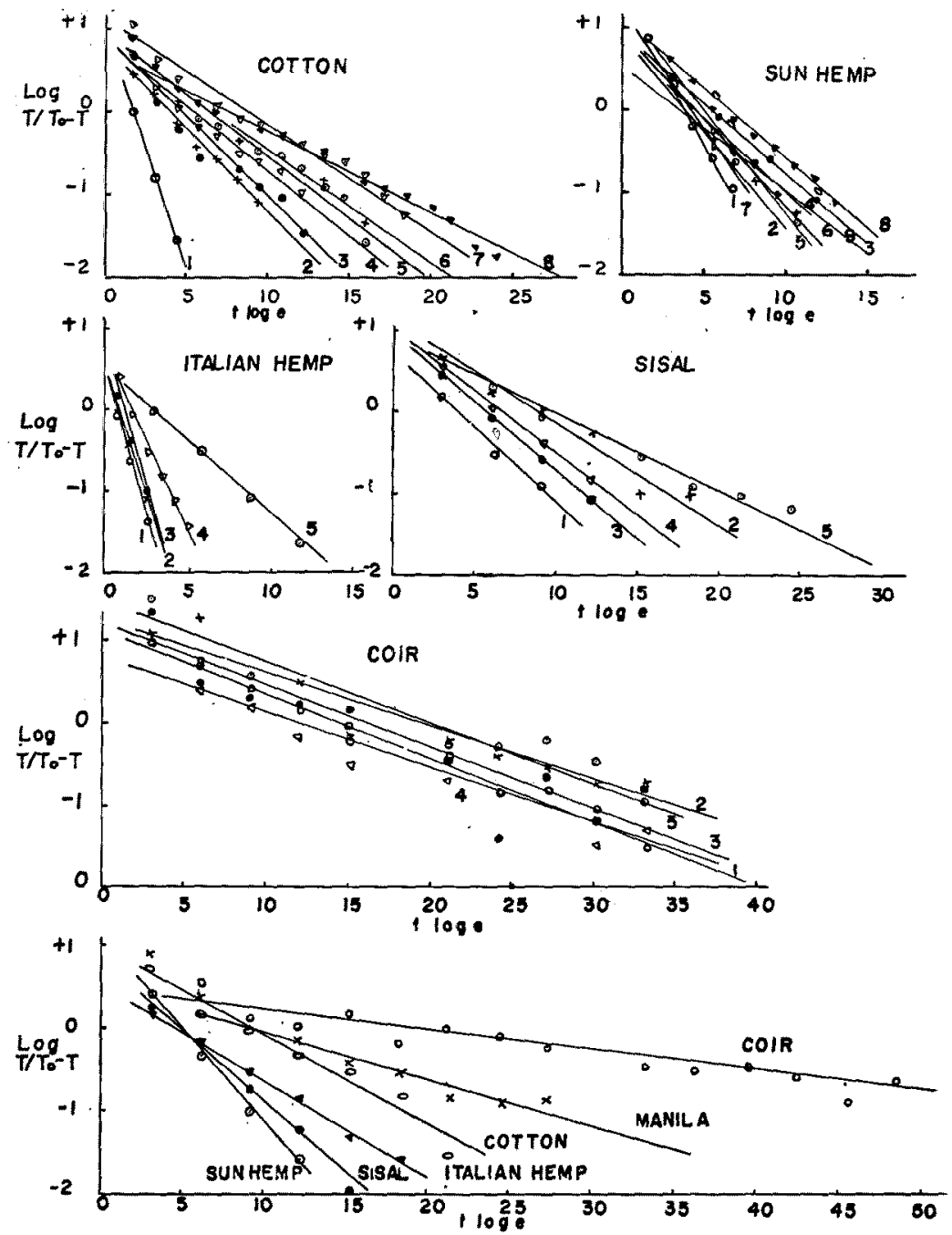

Fig. 2. The relation between $\log \frac{T}{T_{0}-T}$ and $t \log e$. 


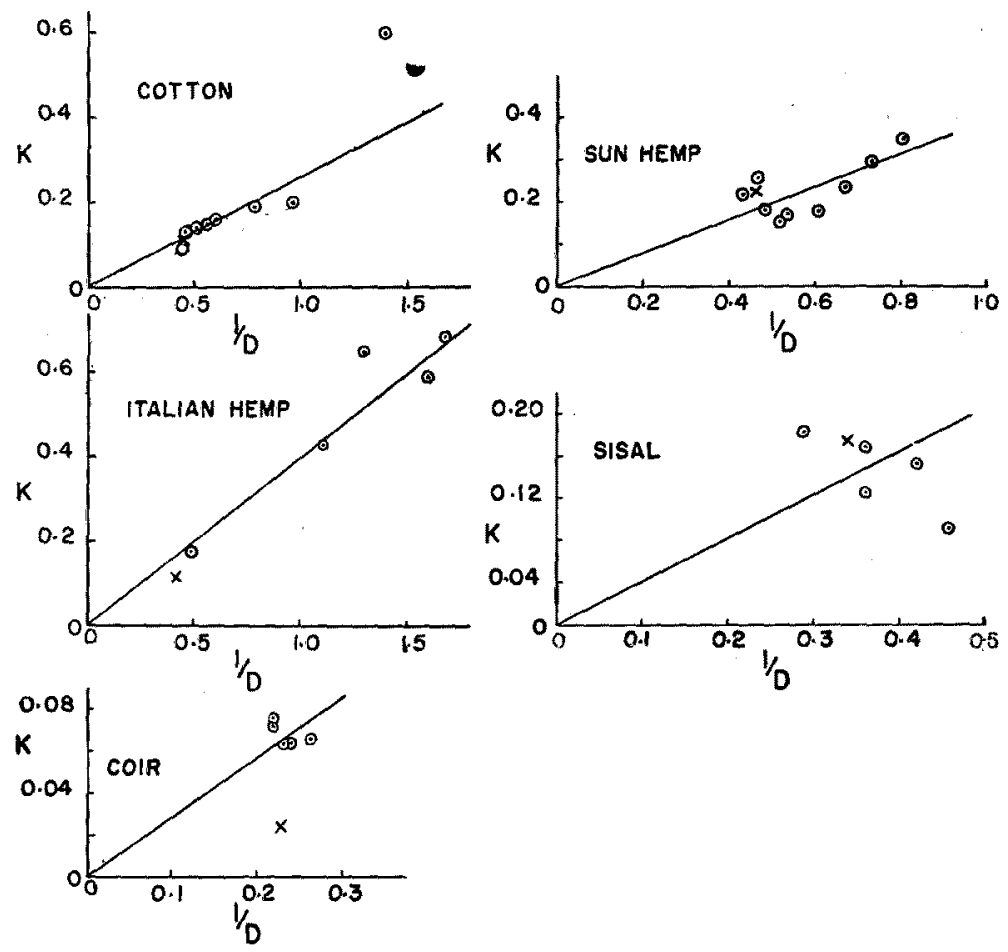

Fig. 3. The relation between rotting coefficient $K$ and one by diameter $\left(\frac{1}{D}\right)$ of the twine.

From"the Text Fig. 3, particularly in the case of cotton sun hemp and Italian hemp.twines the following experimental formula can be deducted.

$$
K=C \frac{1}{D}
$$

Where, $D$ is the diameter of the twine in $\mathrm{mm}$ and $C$ denotes the Constant in the relationship.

In the sisal and coir twines studied the relationship is not so apparent. This might be due to the non-uniformity in the thickness and the strength of these twines reported elsewhere KurIYAN and RAdHALAKSHMI 1960).

By the application of the formula (2) to all the varieties of twines experimented with (vide Text Fig. 3) the values of the constant $C$ were calculated and are as under:

$$
\begin{aligned}
K & =0.27 \times \frac{1}{D} \text { for cotton twine } \\
& =0.40 \times \frac{1}{D} \text { for sun hemp twine }
\end{aligned}
$$


and

$$
\begin{aligned}
& =0.40 \times \frac{1}{D} \text { for Italian hemp twine } \\
& =0.42 \times \frac{1}{D} \text { for sisal twine } \\
& =0.29 \times \frac{1}{D} \text { for coir twine }
\end{aligned}
$$

Smaller the value of $C$ greater is the resistance to rotting. Therefore, when the rotting resistance of twines of different materials of the same diameter are compared, cotton and next to it coir exhibits this property much greater than sun hemp, Italian hemp and sisal. The latter three varieties of twines are obviously considerably weaker in their rot resistance quality. Manila twines (Text Fig. 2) also appear to be strong against rotting although the data available is not sufficient to draw any definite conclusion.

Each group of twines (Table 1) made out of different vegetable fibres were dipped in water on different dates excepting the twines indicated in Table 1 (B). It therefore, appears reasonable to presume that the above evaluations might have to be checked in the different periods of the year to assess as to whether there is any change in the values according to the period of the immersion. It will be seen from Table 2 that although there was considerable variance in the salinity of the test water from June onwards, the temperature was fairly uniform. The rate of rotting of the different twines did not exhibit too much variation in the period during which the study was conducted (vide Text Figs. 1 and 2). It could therefore be assumed that the rotting activity of Cochin backwater, particularly where the experiment was conducted, do not vary much from month to month. The above assumption is substantiated by Text Fig. 3.

A simpler method for comparison of rotting resistance of twines: The relation between the diameter $(D)$ in $\mathrm{mm}$ and the number of days $(N)$ in which each material loses half its original breaking strength is presented in Text Fig. 4. From the Text Figure it could be deducted that $N$ is proportional to $D$ particularly in the case of cotton and Italian hemp.

Therefore,

$$
N=\alpha D
$$

In the case of sun hemp, sisal and coir twines also, although the above relationship is not clear in the Text Fig. 4 due to their being of inferior quality, the above formula can be adopted. The calculated values of the constant $\alpha$ for each variety of: twines are as follows:

$$
\begin{aligned}
N & =6.50 \mathrm{D} \text { for cotton twine } \\
& =5.75 \mathrm{D} \text { for sun hemp twine } \\
& =2.55 \mathrm{D} \text { for Italian hemp twine } \\
& =6.00 \mathrm{D} \text { for Sisal twine }
\end{aligned}
$$



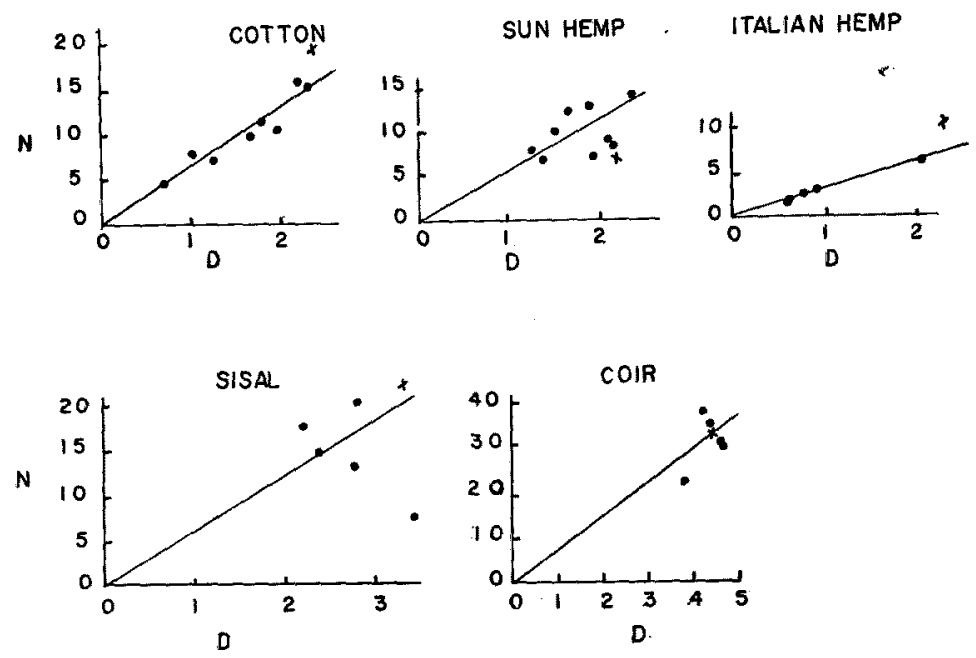

Fig. 4. Relation between diameter $(D \mathrm{~mm})$ and number of days $(N)$ till lose half of the original breaking strength.

and $=7.40 \mathrm{D}$ for coir twine.

Since $D$ in the above formula is in $\mathrm{mm}$ the value of $\alpha$ shows the number of days till $1 \mathrm{~mm}$ diameter of twine loses half its original breaking strength. When the value of $\alpha$ for cotton twine is taken as 100 , then that of sun hemp, Italian hemp, sisal and coir would be $88 \%, 39 \%, 92 \%$ and $113 \%$ respectively.

The value of $K$ in TAurr's formula (1) by which the rotting resistance is represented shows only the degree of rotting of twine after the rotting has commenced and does not take into account the period from actual dipping to the time the rotting commenced. The present authors formula (3) indicated above includes this period as well. Therefore, although TAUTI's formula traces correctly the course of rotting once it has commenced, the present authors formula is more practical for evaluating the rotting resistance which however includes the short period of non-rotting as well.

\section{Summary}

1. Rotting resistance of cotton, sun hemp, Italian hemp, sisal, manila and coir twines immersed in Cochin backwater has been determined.

2. The values of rotting coefficient $K$ in TAUrI's formula $\log \frac{T}{T_{0}-T}=-\left(\begin{array}{lll}K & \log e\end{array}\right)+$ Const. were calculated from the results obtained by the experiments and it was confirmed that the value of $K$ is inversely proportional to the diameter of twines dipped. The values of $K$ worked out are as follows:

$$
K=0.26 \times \frac{1}{D(\mathrm{~mm})} \text { for cotton }
$$




$$
\begin{aligned}
& =0.40 \times \frac{1}{D(\mathrm{~mm})} \text { for sun hemp } \\
& =0.40 \times \frac{1}{D(\mathrm{~mm})} \text { for Italian hemp } \\
& =0.42 \times \frac{1}{D(\mathrm{~mm})} \text { for sisal }
\end{aligned}
$$

and

$$
=0.29 \times \frac{1}{D(\mathrm{~mm})} \text { for coir. }
$$

Higher the value of $K$, the rotting would be quicker.

3. Number of days $N$ till a twine loses half of its original breaking strength is proportional to the diameter of the twine dipped in water, i. e. $N=\alpha D$. Where $\alpha$ is constant and when $D$ the diameter is in $\mathrm{mm}$,

and

$$
\begin{aligned}
N & =6.50 \mathrm{D} \text { for cotton } \\
& =5.75 \mathrm{D} \text { for sun hemp } \\
& =2.55 \mathrm{D} \text { for Italian hemp } \\
& =6.00 \mathrm{D} \text { for sisal } \\
& =7.40 \mathrm{D} \text { for coir. }
\end{aligned}
$$

\section{References}

1) Nishiyama, T. and Yamazoe H.: Jour. Imp. Fish. Inst. 9 (6), 1914.

2) Terada, T.: Ibid. 9 (6), 1914.

3) KaWAI, K.: Ibid. 9 (6), 1914.

4) TAUTI, M.: Ibid. $22(5), 1927$

5) Kanagawa, PREF.: Progress Report of the Kanagawa Prefecture Fisheries Experimental Station for the year 1939.

6) Mryamoto, H. and Shariff, A.T.: Indian Jour. Fish. 6 (2), 1959.

7) TAUTI, M.: Suisan-Butsuri-Danwakai Kaiho, 2, 1929.

8) MiYamoto, H. and Shariff, A.T.: Indian Jour. Fish. 6 (1), 1959.

9) KURIYan, G.K. and RadHalaKshmi: Ibid. 7 (2), 1960. 